\title{
NERIMO IR DEPRESIJOS SIMPTOMŲ RYŠYS SU GYDYMO REŽIMO LAIKYMUSI, SERGANT ÜMINIU MIOKARDO INFARKTU
}

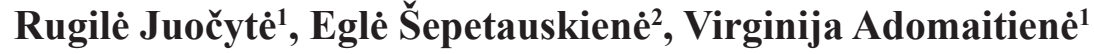 \\ ${ }^{1}$ Lietuvos sveikatos mokslu universiteto Psichiatrijos klinika, \\ ${ }^{2}$ Lietuvos sveikatos mokslu universiteto Informaciniu technologijų centras
}

Raktažodžiai: gydymo režimo laikymasis, ūminis miokardo infarktas, nerimo simptomai, depresijos simptomai.

\section{Santrauka}

Tikslas. Nustatyti ir įvertinti nerimo ir depresijos simptomų ryši su gydymo režimo laikymusi sergant ūminiu miokardo infarktu su ST segmento pakilimu. Tyrimo metodai. Tiriamieji apklausti naudojantis autorių sudarytu sociodemografiniu klausimynu, standartizuotu gydymosi režimo laikymosi klausimynu (angl. Morisky Medication Adherence Scale, santrumpa - MMAS-8) ir ligoninès nerimo ir depresijos vertinimo skale (angl. Hospital Anxiety and Depression Scale, santrumpa - HADS). Statistinè duomenu analizè atlikta naudojant SPSS20 ir Microsoft Office Excel 2010. Nagrinejjami požymiai vertinti skaičiuojant aritmetinị vidurkị ir standartinị nuokrypị. Tikrinat statistines hipotezes, reikšmingumo lygmuo pasirinktas kai p lygus 0,05 .

Rezultatai. Nustatyta, kad blogai gydymo režimo laikèsi 47,2 proc., vidutiniškai - 31,5 proc., gerai - 21,3 proc. tiriamujų, sergančių miokardo infarktu su ST segmento pakilimu. Nežymūs nerimo simptomai nustatyti 28,4 proc., vidutiniai - 10,2 proc., sunkūs - 1 proc. tiriamujų, sergančių miokardo infarktu su ST segmento pakilimu, o reikšmingo ryšio tarp gydymo režimo laikymosi ir nerimo simptomų raiškos nenustatyta. Blogas gydymo režimo laikymasis, sergant miokardo infarktu su ST segmento pakilimu, reikšmingai susijęs su lengva nerimo simptomų raiška tarp nedirbančių/esančių pensijoje tiriamujų ir moterų. Lengvi depresijos simptomai nustatyti 16,2 proc., vidutiniai $-2,0$ proc., sunkūs $-0,5$ proc. tiriamuju. Depresijos simptomai statistiškai reikšmingai susiję su gydymo režimo laikymusi. Nustatyta, kad blogai gydymo režimo laikèsi lengvus depresijos simpto- mus patiriantys $\geq 65$ metų amžiaus, nedirbantys bei aukštesnio išsimokslinimo tiriamieji.

\section{Ivadas}

Širdies ir kraujagyslių ligos yra pagrindinè mirties priežastis visame pasaulyje. Nuo širdies ir kraujagyslių ligų kiekvienais metais miršta $17,7 \mathrm{mln}$. žmonių, o tai sudaro 31 proc. visų mirties priežasčių, iš kurių 7,4 mln. dèl išeminès širdies ligos [1]. Miokardo infarktas - miokardo funkcijos sutrikimas dèl vainikinių kraujagyslių perfuzijos lygio ir miokardo energijos poreikio skirtumų [2]. Ilgalaikè išemija, deguonies trūkumas lemia miokardo ląstelių žūtị ir širdies nekrozę [3]. Ši liga dažnai nulemia nepalankias klinikines baigtis (blogiausia prognozè išgyvenus miokardo infarktą su ST segmento pakilimu), stipriai pablogina asmenų funkcinę būklę ir bendrą sveikatą [4]. Miokardo infarktas su ST segmento pakilimu (STEMI) - negrịžtamas širdies raumens dalies pažeidimas ir žuvimas, kuris atsiranda dèl širdies kraujotakos pablogèjimo, trombui užkimšus vainikinę kraujagyslę. Elektrokardiogramoje matomas ST segmento pakilimas [5]. Moksliniuose tyrimuose nustatomas ryšys tarp MI sergančių pacientų gydymo režimo nesilaikymo, nerimo, depresijos simptomų, kardiologinès ligos raiškos [6]. Gydytojo ir paciento bendradarbiavimas gydymo procese bei gydytojo paskirtų vaistų vartojimo režimo laikymasis yra vienas svarbiausių veiksnių, turinčių įtakos sveikatos priežiūros paslaugų kokybei [7]. Gydymo režimo laikymasis apibrèžiamas kaip paciento elgesys - vartojant medikamentus, laikantis dietos ar keičiant gyvenimo būdą - kuris atitinka sveikatos priežiūros specialisto rekomendacijas [8].

Tyrimo tikslas: nustatyti ir ịvertinti nerimo ir depresijos simptomų ryšị su gydymo režimo laikymusi, sergant ūminiu miokardo infarktu su ST segmento pakilimu.

\section{Tyrimo objektas ir metodai}

Tyrimas atliktas Lietuvos sveikatos mokslų universiteto 
ligoninės Kauno klinikų (LSMUL Kauno klinikos) kardiologijos klinikoje 2017.01.30 iki 2018.11.20 laikotarpiu. Standartizuotos anketinès, atsitiktinès atrankos būdu (kas 3-ias sergantis STEMI pacientas) buvo apklausti 200 STEMI sergančiu pacientų (TLK-10-AM klasifikacijoje diagnozè koduojama I21.0, I21.1, I21.2), praejjus ne mažiau kaip trims dienoms po patirto miokardo infarkto su ST segmento pakilimu. I tyrimą nebuvo ịtraukti pacientai, kuriems anamnezeje diagnozuoti psichikos ir elgesio sutrikimai.

Tiriamujų imties charakteristikoms nustatyti naudotas autorių sudarytas sociodemografinis klausimynas, vertinantis tiriamujų lyti, amžių, šeiminę padètị, darbingumo lygmenị, išsimokslinimą, gaunamas asmenines mènesio pajamas, gyvenamą vietą.

Tiriamuju gydymosi režimo laikymasis buvo vertinamas MMAS - 8 skale, leidžiančia išskirti tris tiriamujų grupes (geras gydymo režimo laikymasis, vidutinis gydymo režimo laikymasis ir gydymo režimo nesilaikymas). I pirmus septynis klausimus reikejjo atsakyti teigiamai arba neigiamai. Už teigiamą atsakymą buvo skiriama 0 balų, o už neigiamą -1 balas. I aštuntajji klausimą galima buvo pasirinkti tinkantį atsakymą iš 5 variantų: ,niekada“- 4 balai, ,beveik niekada” - 3 balai, ,kartais”-2 balai, ,dažnai“ - 1 balas, „beveik niekada” - 0 balų. Aštuntojo klausimo balai padalinti iš 4 ir susumuoti su visais surinktais balais. Respondentai, surinkę $<6$ balus, buvo priskirti blogo gydymo režimo laikymosi grupei, surinkę 6 - 7 balus - vidutinio, 8 - balus - gero gydymo režimo laikymosi grupei.

Depresijos ir nerimo simptomams vertinti naudota ligoninès nerimo ir depresijos skale (HADS), kurią sudaro 14 klausimų. Tai savęs vertinimo įrankis, sukurtas nustatyti depresijos ir nerimo simptomus ir jų sunkumą per praejjusią savaitę. Kiekvienas klausimas turi keturis atsakymo variantus, atitinkamai vertinamus nuo 0 iki 3 balų. Buvo skaičiuojami nerimo subskalejje (HADN) ir depresijos subskaleje (HADD) surinkti balai. HADD (2, $4,6,8,10,12,14$ klausimai) ir $\operatorname{HADN}(1,3$, $5,7,9,11,13$ klausimai) subskalių rezultatai buvo vertinti vienodai: 0 - 7 balai - vertinta kaip norma; 8 - 10 balų - vertinta kaip len-
1 lentelè. Tiriamųjų, sergančių miokardo infarktu su ST segmento pakilimu, sociodemografinès charakteristikos.

\begin{tabular}{|l|c|c|c|c|c|}
\hline \multirow{2}{*}{ Kategorija } & Kintamieji & \multicolumn{2}{|c|}{ Lytis } & Iš viso & \multirow{2}{*}{$\mathbf{P}\left(\boldsymbol{\chi}^{2}\right)$} \\
\cline { 3 - 5 } & & $\begin{array}{c}\text { Vyrai } \\
\text { n (proc.) }\end{array}$ & Moterys \\
n (proc.) & & \\
\hline Amžius & $<65 \mathrm{~m}$. & $91(61,5)$ & $5(9,6)$ & $96(48,0)$ & 0,0001 \\
& $\geq 65 \mathrm{~m}$. & $57(38,5)$ & $47(90,4)$ & $104(52,0)$ & $(41,480)$ \\
\hline Išsilavinimas & $\leq 12 \mathrm{~m}$. & $81(54,7)$ & $29(55,8)$ & $110(55,0)$ & 0,897 \\
(metais) & $>12 \mathrm{~m}$. & $67(45,3)$ & $23(44,2)$ & $90(45,0)$ & $(0,017)$ \\
\hline Šeiminė & Gyvena poroje & $128(87,1)$ & $17(32,7)$ & $145(72,9)$ & 0,0001 \\
padėtis & Vienišas (a) & $19(12,9)$ & $35(67,3)$ & $54(27,1)$ & $(57,455)$ \\
\hline Darbingumas & Dirba & $66(47,8)$ & $4(8,0)$ & $70(37,2)$ & 0,0001 \\
& Pensininkas / nedirba & $34(24,6)$ & $36(72,0)$ & $70(37,2)$ & $(38,608)$ \\
& Pensininkas / dirba & $10(7,2)$ & $3(6,0)$ & $13(6,9)$ & \\
& Neigalus & $28(20,3)$ & $7(14,0)$ & $35(18,6)$ & \\
\hline Mėnesio & $<380$, eur. & $70(47,3)$ & $42(80,8)$ & $112(56,0)$ & 0,001 \\
pajamos & $381-760$, eur. & $48(32,4)$ & $6(11,5)$ & $54(27,0)$ & $(19,708)$ \\
& $761-1000$, eur. & $12(8,1)$ & $1(1,9)$ & $13(6,5)$ & \\
& $>1000$, eur. & $10(6,8)$ & $0(0,0)$ & $10(5,0)$ & \\
& Pajamų negauna & $8(5,4)$ & $3(5,8)$ & $11(5,5)$ & \\
\hline Gyvenamoji & Miestas & $97(65,5)$ & $37(71,2)$ & $134(67,0)$ & 0,459 \\
vieta & Kaimas & $51(34,5)$ & $15(28,8)$ & $66(33,0)$ & $(0,548)$ \\
\hline
\end{tabular}

2 lentelè. Gydymo režimo laikymosi sąsajos su sociodemografiniais veiksniais.

\begin{tabular}{|c|c|c|c|c|c|c|}
\hline \multirow{2}{*}{$\begin{array}{l}\text { Katego- } \\
\text { rija }\end{array}$} & \multirow[t]{2}{*}{ Kintamieji } & \multicolumn{3}{|c|}{ Gydymo režimo laikymasis } & \multirow{2}{*}{$\begin{array}{c}\text { Iš viso } \\
\text { n (proc.) }\end{array}$} & \multirow[t]{2}{*}{$\mathbf{P}\left(\chi^{2}\right)$} \\
\hline & & $\begin{array}{c}\text { Blogas } \\
\text { n (proc.) }\end{array}$ & $\begin{array}{l}\text { Vidutinis } \\
\text { n (proc.) }\end{array}$ & $\begin{array}{c}\text { Geras } \\
\text { n (proc.) }\end{array}$ & & \\
\hline Amžius & $\begin{array}{l}<65 \mathrm{~m} . \\
\geq 65 \mathrm{~m} .\end{array}$ & $\begin{array}{l}41(44,1) \\
52(55,9)\end{array}$ & $\begin{array}{l}29(46,8) \\
33(53,2)\end{array}$ & $\begin{array}{l}24(57,1) \\
18(42,9)\end{array}$ & $\begin{array}{c}94(47,7) \\
103 \\
(52,3)\end{array}$ & $\begin{array}{c}0,366 \\
(2,009)\end{array}$ \\
\hline $\begin{array}{l}\text { Išsilavi- } \\
\text { nimas } \\
\text { (metais) }\end{array}$ & $\begin{array}{l}\leq 12 \mathrm{~m} . \\
>12 \mathrm{~m} .\end{array}$ & $\begin{array}{l}52(55,9) \\
41(44,1)\end{array}$ & $\begin{array}{l}34(54,8) \\
28(45,2)\end{array}$ & $\begin{array}{l}23(54,8) \\
19(45,2)\end{array}$ & $\begin{array}{c}109 \\
(55,3) \\
88(44,7) \\
\end{array}$ & $\begin{array}{c}0,988 \\
(0,024)\end{array}$ \\
\hline Lytis & $\begin{array}{l}\text { Vyras } \\
\text { Moteris }\end{array}$ & $\begin{array}{l}71(76,3) \\
22(23,7)\end{array}$ & $\begin{array}{l}42(67,7) \\
20(32,3)\end{array}$ & $\begin{array}{c}33(78,6) \\
9(21,4)\end{array}$ & $\begin{array}{c}146 \\
(74,1) \\
51(25,9)\end{array}$ & $\begin{array}{c}0,370 \\
(1,988)\end{array}$ \\
\hline $\begin{array}{l}\text { Šeimine } \\
\text { padètis }\end{array}$ & $\begin{array}{c}\text { Gyvena poroje } \\
\text { Vienišas (a) }\end{array}$ & $\begin{array}{l}67(72,0) \\
26(28,0)\end{array}$ & $\begin{array}{l}46(75,4) \\
15(24,6)\end{array}$ & $\begin{array}{l}30(71,4) \\
12(28,6)\end{array}$ & $\begin{array}{c}143 \\
(73,0) \\
53(27,0)\end{array}$ & $\begin{array}{c}0,871 \\
(0,275)\end{array}$ \\
\hline $\begin{array}{l}\text { Darbin- } \\
\text { gumas }\end{array}$ & $\begin{array}{c}\text { Dirba } \\
\text { Pensininkas ir } \\
\text { nedirba } \\
\text { Pensininkas ir } \\
\text { dirba } \\
\text { Neigalusis }\end{array}$ & $\begin{array}{c}29(32,2) \\
36(40,0) \\
8(8,9) \\
17(18,9) \\
0(0,0)\end{array}$ & $\begin{aligned} 20 & (35,7) \\
22 & (39,3) \\
2 & (3,6) \\
12 & (21,4) \\
0 & (0,0)\end{aligned}$ & $\begin{array}{c}20(50,0) \\
12(30,0) \\
2(5,0) \\
6(15,0) \\
0(0,0)\end{array}$ & $\begin{array}{c}69(37,1) \\
70(37,6) \\
12(6,5) \\
35(18,8) \\
0(0,0)\end{array}$ & $\begin{array}{c}0,495 \\
(5,387)\end{array}$ \\
\hline $\begin{array}{l}\text { Mènesio } \\
\text { pajamos }\end{array}$ & $\begin{array}{c}\text { <380, eur. } \\
\text { 381-760, eur. } \\
\text { 761-1000, eur. } \\
>1000 \text {, eur. } \\
\text { Pajamų } \\
\text { negauna }\end{array}$ & $\begin{array}{c}52(55,9) \\
23(24,7) \\
7(7,5) \\
5(5,4) \\
6(6,5)\end{array}$ & $\begin{array}{c}36(58,1) \\
15(24,2) \\
3(4,8) \\
4(6,5) \\
4(6,5)\end{array}$ & $\begin{array}{c}24(57,1) \\
15(35,7) \\
2(4,8) \\
1(2,4) \\
0(0,0)\end{array}$ & $\begin{array}{c}112(56,9) \\
53(26,9) \\
12(6,1) \\
10(5,1) \\
10(5,1)\end{array}$ & $\begin{array}{c}0,677 \\
(5,730)\end{array}$ \\
\hline $\begin{array}{l}\text { Gyvena- } \\
\text { moji vieta }\end{array}$ & $\begin{array}{l}\text { Miestas } \\
\text { Kaimas }\end{array}$ & $\begin{array}{l}59(63,4) \\
34(36,6)\end{array}$ & $\begin{array}{l}47(75,8) \\
15(24,2)\end{array}$ & $\begin{array}{l}26(61,9) \\
16(38,1)\end{array}$ & $\begin{array}{c}132 \\
(67,0) \\
65(33,0)\end{array}$ & $\begin{array}{c}0,202 \\
(3,201)\end{array}$ \\
\hline
\end{tabular}


3 lentelè. Nerimo simptomų raiškos sąsajos su gydymo režimo laikymusi.

\begin{tabular}{|c|c|c|c|c|c|c|}
\hline \multirow[t]{2}{*}{ Kategorija } & \multirow[t]{2}{*}{ Kintamieji } & \multicolumn{3}{|c|}{ Gydymo režimo laikymasis } & \multirow{2}{*}{$\begin{array}{l}\text { Iš viso } \\
\text { n (proc.) }\end{array}$} & \multirow[t]{2}{*}{$\mathbf{P}\left(\chi^{2}\right)$} \\
\hline & & $\begin{array}{l}\text { Blogas } \\
\text { n (proc.) }\end{array}$ & $\begin{array}{l}\text { Vidutinis } \\
\text { n (proc.) }\end{array}$ & $\begin{array}{l}\text { Geras } \\
\text { n (proc.) }\end{array}$ & & \\
\hline Nerimas & $\begin{array}{l}\text { Norma } \\
\text { Lengvas } \\
\text { Vidutinis } \\
\text { Sunkus }\end{array}$ & $\begin{array}{l}50(53,8) \\
30(32,3) \\
12(12,9) \\
1(1,1)\end{array}$ & $\begin{array}{l}41(66,1) \\
15(24,2) \\
5(8,1) \\
1(1,6)\end{array}$ & $\begin{array}{l}28(66,7) \\
11(26,2) \\
3(7,1) \\
0(0,0)\end{array}$ & $\begin{array}{l}119(60,4) \\
56(28,4) \\
20(10,2) \\
2(1,0)\end{array}$ & $0,648(4,215)$ \\
\hline
\end{tabular}

4 lentelè. Nerimo simptomų raiškos sąsajos su gydymo režimo laikymusi ir siociodemografiniais veiksniais.

\begin{tabular}{|c|c|c|c|c|c|c|c|}
\hline \multirow[t]{2}{*}{ Kategorija } & \multirow[t]{2}{*}{ Kintamieji } & \multirow[t]{2}{*}{ Nerimas } & \multicolumn{3}{|c|}{ Gydymo režimo laikymasis } & \multirow{2}{*}{$\begin{array}{c}\text { Iš viso } \\
\text { n (proc.) }\end{array}$} & \multirow[t]{2}{*}{$\mathbf{P}\left(\chi^{2}\right)$} \\
\hline & & & $\begin{array}{c}\text { Blogas } \\
\text { n (proc.) }\end{array}$ & $\begin{array}{l}\text { Vidutinis } \\
\text { n (proc.) }\end{array}$ & $\begin{array}{c}\text { Geras } \\
\text { n (proc.) }\end{array}$ & & \\
\hline \multirow[t]{2}{*}{ Lytis } & Vyras & $\begin{array}{l}\text { Norma } \\
\text { Lengvas } \\
\text { Vidutinis } \\
\text { Sunkus } \\
\end{array}$ & $\begin{array}{c}47(66,2) \\
18(25,4) \\
6(8,5) \\
0(0,0) \\
\end{array}$ & $\begin{array}{c}26(61,9) \\
12(28,6) \\
3(7,1) \\
1(2,4) \\
\end{array}$ & $\begin{array}{c}23(69,7) \\
9(27,3) \\
1(3,0) \\
0(0) \\
\end{array}$ & $\begin{array}{c}96(65,8) \\
39(26,7) \\
10(6,8) \\
1(0,7) \\
\end{array}$ & $\begin{array}{c}0,713 \\
(3,732)\end{array}$ \\
\hline & Moteris & $\begin{array}{l}\text { Norma } \\
\text { Lengvas } \\
\text { Vidutinis } \\
\text { Sunkus } \\
\end{array}$ & $\begin{array}{c}3(13,6) \\
12(54,5) \\
6(27,3) \\
1(4,5) \\
\end{array}$ & $\begin{array}{c}15(75,0) \\
3(15,0) \\
2(10,0) \\
0(0,0) \\
\end{array}$ & $\begin{array}{c}5(55,6) \\
2(22,2) \\
2(22,2) \\
0(0,0) \\
\end{array}$ & $\begin{array}{c}23(45,1) \\
17(33,3) \\
10(19,6) \\
1(2,0) \\
\end{array}$ & $\begin{array}{c}0,008 \\
(17,282)\end{array}$ \\
\hline \multirow[t]{4}{*}{$\begin{array}{l}\text { Darbingu- } \\
\text { mas }\end{array}$} & Dirba & $\begin{array}{l}\text { Norma } \\
\text { Lengvas } \\
\text { Vidutinis }\end{array}$ & $\begin{array}{c}20(69,0) \\
6(20,7) \\
3(10,3)\end{array}$ & $\begin{array}{c}15(75,0) \\
3(15,0) \\
2(10,0)\end{array}$ & $\begin{array}{c}14(70,0) \\
5(25,0) \\
1(5,0)\end{array}$ & $\begin{array}{c}49(71,0) \\
14(20,3) \\
6(8,7)\end{array}$ & $\begin{array}{c}0,909 \\
(1,006)\end{array}$ \\
\hline & $\begin{array}{l}\text { Pensininkas } \\
\text { ir nedirba }\end{array}$ & \begin{tabular}{|l} 
Norma \\
Lengvas \\
Vidutinis \\
Sunkus \\
\end{tabular} & $\begin{array}{c}11(30,6) \\
17(47,2) \\
7(19,4) \\
1(2,8)\end{array}$ & $\begin{array}{c}16(72,7) \\
4(18,2) \\
2(9,1) \\
0(0,0)\end{array}$ & $\begin{array}{c}8(66,7) \\
3(25,0) \\
1(8,3) \\
0(0,0)\end{array}$ & $\begin{array}{c}35(50,0) \\
24(34,3) \\
10(14,3) \\
1(1,4)\end{array}$ & $\begin{array}{c}0,008 \\
(6,951)\end{array}$ \\
\hline & $\begin{array}{l}\text { Pensininkas } \\
\text { ir dirba }\end{array}$ & $\begin{array}{l}\text { Norma } \\
\text { Lengvas } \\
\text { Vidutinis } \\
\end{array}$ & $\begin{array}{c}5(62,5) \\
3(37,5) \\
0(0,0)\end{array}$ & $\begin{array}{c}1(50,0) \\
1(50,0) \\
0(0,0)\end{array}$ & $\begin{array}{c}1(50,0) \\
0(0,0) \\
1(50,0)\end{array}$ & $\begin{array}{c}7(58,3) \\
4(33,3) \\
1(8,3)\end{array}$ & $\begin{array}{c}0,203 \\
(5,946)\end{array}$ \\
\hline & Neigalusis & \begin{tabular}{|l|} 
Norma \\
Lengvas \\
Vidutinis \\
Sunkus
\end{tabular} & $\begin{array}{c}1(64,7) \\
4(23,5) \\
2(11,8) \\
0(0,0)\end{array}$ & $\begin{array}{c}6(50,0) \\
4(33,3) \\
1(8,3) \\
1(8,3)\end{array}$ & $\begin{array}{c}4(66,7) \\
2(33,3) \\
0(0,0) \\
0(0,0)\end{array}$ & $\begin{array}{c}21(60,0) \\
10(28,6) \\
3(8,6) \\
1(2,9)\end{array}$ & $\begin{array}{c}0,779 \\
(3,235)\end{array}$ \\
\hline
\end{tabular}

5 lentelè. Depresijos simptomų raiškos sąsajos su gydymo režimo laikymusi.

\begin{tabular}{|c|c|c|c|c|c|c|}
\hline \multirow[t]{2}{*}{ Kategorija } & \multirow[t]{2}{*}{ Kintamieji } & \multicolumn{3}{|c|}{ Gydymo režimo laikymasis } & \multirow{2}{*}{$\begin{array}{l}\text { Iš viso } \\
\text { n (proc.) }\end{array}$} & \multirow[t]{2}{*}{$\mathbf{P}\left(\chi^{2}\right)$} \\
\hline & & $\begin{array}{l}\text { Blogas } \\
\text { n (proc.) }\end{array}$ & $\begin{array}{l}\text { Vidutinis } \\
\text { n (proc.) }\end{array}$ & $\begin{array}{l}\text { Geras } \\
\text { n (proc.) }\end{array}$ & & \\
\hline Depresija & $\begin{array}{l}\text { Norma } \\
\text { Lengvas } \\
\text { Vidutinis } \\
\text { Sunkus }\end{array}$ & $\begin{array}{l}67(72,0) \\
21(22,6) \\
4(4,3) \\
1(1,1)\end{array}$ & \begin{tabular}{|l|}
$55(88,7)$ \\
$7(11,3)$ \\
$0(0,0)$ \\
$0(0,0)$
\end{tabular} & $\begin{array}{l}38(90,5) \\
4(9,5) \\
0(0,0 \\
0(0,0)\end{array}$ & $\begin{array}{l}160(81,3) \\
32(16,2) \\
4(2,0) \\
1(0,5)\end{array}$ & $\begin{array}{l}0,032 \\
(13,822)\end{array}$ \\
\hline
\end{tabular}

gvas sutrikimas; 11 - 14 balų - vertinta kaip vidutinis sutrikimas; 15 - 21 balas - vertinta kaip sunkus sutrikimas.

Statistinè duomenų analizè atlikta naudojant kompiuterinès programos statistikos paketą SPSS 20.0 (Statistical Package for Social Sciences) ir Microsoft Office Excel 2010. Gautiems duomenims vertinti reikšmingumo lygmuo pasirinktas 0,05 . Analizei taikytas susijusių lentelių metodas, o kokybinių požymių tarpusavio priklausomu- mas vertintas tiksliuoju $\chi^{2}$ (chi kvadratas) kriterijumi (mažoms imtims) ir asimptotiniu $\chi^{2}$ (chi kvadratas) kriterijumi.

\section{Tyrimo rezultatai}

Tyrime dalyvavo 200 tiriamųjų, sergančių STEMI, iš kurių 74 proc. (148/200) buvo vyrai (1 lentelè).

Nustatyta, kad STEMI sergantys vyrai amžiumi buvo reikšmingai jaunesni nei moterys (61,5 proc. ir 9,6 proc.), o moterys reikšmingai vyresnès $(90,4$ proc. ir 38,5 proc., $\mathrm{p}=0,0001)$. Sergantys STEMI vyrai reikšmingai dažniau gyveno poroje $(87,1$ proc. ir 32,7 proc.) ir buvo dirbantys $(47,8$ proc. ir 8,0 proc., $\mathrm{p}=0,0001$ ), o moterys reikšmingai dažniau buvo vienišos (67,3 proc. ir 12,9 proc.) ir nedirbo ( 72,0 proc. ir $24,6$ proc., $\mathrm{p}=0,0001)$. Taip pat nustatyta, kad sergančios STEMI moterys reikšmingai dažniau nei vyrai gavo minimalias mėnesio pajamas $(80,8$ proc. ir 47,3 proc.), o vyrai reikšmingai dažniau iki dviejų kartų didesnes ménesio pajamas nei moterys $(32,4$ proc. ir 11,5 proc., $\mathrm{p}=0,001)$.

Nenustatyta reikšmingo skirtumo tarp lyčių vertinant STEMI sergančius tiriamuosius pagal išsimokslinimą ir gyvenamą vietą.

Gydymo režimo laikymosi klausimyną teisingai užpilde 197 (98,5 proc.) STEMI sergantys tiriamieji, iš kurių 42 (21,3 proc.) nurodè, kad gydymo režimo laikosi gerai, 62 (31,5 proc.) vidutiniškai, o 93 (47,2 proc.) blogai. Nenustatyta statistiškai reikšmingo ryšio tarp gydymo režimo laikymosi ir STEMI sergančių tiriamųjų sociodemografinių veiksnių (amžiaus, 
lyties, išsimokslinimo, šeiminès padèties, darbingumo, gaunamų ménesio pajamų, gyvenamosios vietos, 2 lentelè).

Nerimo simptomų raiškos vertinimo subskalę teisingai užpilde 197 (98,5 proc.) STEMI sergantys tiriamieji. Nerimo simptomų raiška vertinta kaip normali 119 (60,0 proc.) tiriamųjų, lengvi nerimo simptomai nustatyti 56 ( 28,4 proc.), vidutinè nerimo simptomų raiška 20 (10,2 proc.) ir sunkūs nerimo simptomai - 2 (1,0 proc.) STEMI sergantiems tiriamiesiems. Statistiškai reikšmingo ryšio tarp gydymo režimo laikymosi ir nerimo simptomų raiškos nenustatyta (3 lentelè).

Nustatyta, kad reikšmingai dažniau blogai gydymo režimo laikèsi lengvus nerimo simptomus patiriančios moterys $(54,5$ proc. ir 15,0 proc. ir 22,2 proc., $\mathrm{p}=0,008)$ ir nedirbantys STEMI sergantys tiriamieji $(47,2$ proc. ir 18,2 proc. ir 25,0 proc., $\mathrm{p}=$ 0,008; 4 lentelè).

Depresijos simptomų raiškos vertinimo subskalę teisingai užpildẻ 197 (98,5 proc.) STEMI sergantys tiriamieji. Depresijos simptomų raiška vertinta kaip normali 160 (81,3 proc.) tiriamujų, lengvi depresijos simptomai nustatyti 32 (16,2 proc.), vidutine depresijos simptomy raiška - 4 (2,0 proc.) ir sunkūs depresijos simptomai - $1(0,5$ proc.) STEMI sergančiam tiriamajam (5 lentelè).

Blogai gydymo režimo laikèsi STEMI sergantys tiriamieji, kuriems nustatyti lengvi depresijos simptomai $(22,6$ proc. ir 11,3 proc. ir 9,5 proc., $\mathrm{p}=0,032$ ).

Taip pat nustatyta, kad blogai gydymo režimo laikèsi lengvus depresijos simptomus patiriantys
6 lentelè. Depresijos simptomų raiškos sąsajos su gydymo režimo laikymusi ir sociodemografiniais veiksniais.

\begin{tabular}{|c|c|c|c|c|c|c|c|}
\hline \multirow[t]{2}{*}{ Kategorija } & \multirow[t]{2}{*}{ Kintamieji } & \multirow[t]{2}{*}{ Depresija } & \multicolumn{3}{|c|}{ Gydymo režimo laikymasis } & \multirow{2}{*}{$\begin{array}{c}\text { Iš viso } \\
\text { n (proc.) }\end{array}$} & \multirow[t]{2}{*}{$\mathbf{P}\left(\chi^{2}\right)$} \\
\hline & & & $\begin{array}{c}\text { Blogas } \\
\text { n (proc.) }\end{array}$ & $\begin{array}{l}\text { Vidutinis } \\
\text { n (proc.) }\end{array}$ & $\begin{array}{c}\text { Geras } \\
\text { n (proc.) }\end{array}$ & & \\
\hline \multirow[t]{2}{*}{ Amžius } & $<65 \mathrm{~m}$. & $\begin{array}{l}\text { Norma } \\
\text { Lengvas } \\
\text { Vidutinis }\end{array}$ & $\begin{array}{c}35(85,4) \\
4(9,8) \\
2(4,9)\end{array}$ & $\begin{array}{c}28(96,6) \\
1(3,4) \\
0(0,0)\end{array}$ & $\begin{array}{c}21(87,5) \\
3(12,5) \\
0(0,0)\end{array}$ & $\begin{array}{c}84(89,4) \\
8(8,5) \\
2(2,1)\end{array}$ & $\begin{array}{c}0,375 \\
(4,232)\end{array}$ \\
\hline & $\geq 65 \mathrm{~m}$. & $\begin{array}{l}\text { Norma } \\
\text { Lengvas } \\
\text { Vidutinis } \\
\text { Sunkus }\end{array}$ & $\begin{array}{c}32(61,5) \\
17(32,7) \\
2(3,8) \\
1(1,9)\end{array}$ & $\begin{array}{c}27(81,8) \\
6(18,2) \\
0(0,0) \\
0(0,0)\end{array}$ & $\begin{array}{c}17(94,4) \\
1(5,6) \\
0(0,0) \\
0(0,0)\end{array}$ & $\begin{array}{c}76(73,8) \\
24(23,3) \\
2(1,9) \\
1(1,0)\end{array}$ & $\begin{array}{c}0,003 \\
(8,932)\end{array}$ \\
\hline \multirow[t]{2}{*}{$\begin{array}{l}\text { Išsilavini- } \\
\text { mas } \\
\text { (metais) }\end{array}$} & $\leq 12 \mathrm{~m}$. & $\begin{array}{l}\text { Norma } \\
\text { Lengvas } \\
\text { Vidutinis } \\
\text { Sunkus }\end{array}$ & $\begin{array}{c}39(75,0) \\
8(15,4) \\
4(7,7) \\
1(1,9)\end{array}$ & $\begin{array}{c}29(85,3) \\
5(14,7) \\
0(0,0) \\
0(0,0)\end{array}$ & $\begin{array}{c}20(87,0) \\
3(13,0) \\
0(0,0) \\
0(0,0)\end{array}$ & $\begin{array}{c}88(80,7) \\
16(14,7) \\
4(3,7) \\
1(0,9)\end{array}$ & $\begin{array}{c}0,429 \\
(5,950)\end{array}$ \\
\hline & $>12 \mathrm{~m}$ & $\begin{array}{l}\text { Norma } \\
\text { Lengvas }\end{array}$ & $\begin{array}{l}28(68,3) \\
13(31,7)\end{array}$ & $\begin{array}{c}26(92,9) \\
2(7,1)\end{array}$ & $\begin{array}{c}18(94,7) \\
1(5,3)\end{array}$ & $\begin{array}{l}72(81,8) \\
16(18,2)\end{array}$ & $\begin{array}{c}0,009 \\
(9,467)\end{array}$ \\
\hline \multirow[t]{4}{*}{$\begin{array}{l}\text { Darbingu- } \\
\text { mas }\end{array}$} & Dirba & $\begin{array}{l}\text { Norma } \\
\text { Lengvas } \\
\text { Vidutinis }\end{array}$ & $\begin{array}{c}23(79,3) \\
4(13,8) \\
2(6,9)\end{array}$ & $\begin{array}{c}20(100,0) \\
0(0,0) \\
0(0,0)\end{array}$ & $\begin{array}{c}17(85,0) \\
3(15,0) \\
0(0,0)\end{array}$ & $\begin{array}{c}60(87,0) \\
7(10,1) \\
2(2,9)\end{array}$ & $\begin{array}{c}0,183 \\
(6,228)\end{array}$ \\
\hline & $\begin{array}{l}\text { Pensininkas } \\
\text { ir nedirba }\end{array}$ & $\begin{array}{l}\text { Norma } \\
\text { Lengvas } \\
\text { Vidutinis }\end{array}$ & $\begin{array}{c}21(58,3) \\
14(38,9) \\
1(2,8)\end{array}$ & $\begin{array}{c}18(81,8) \\
4(18,2) \\
0(0,0)\end{array}$ & $\begin{array}{c}11(91,7) \\
1(8,3) \\
0(0,0)\end{array}$ & $\begin{array}{c}50(71,4) \\
19(27,1) \\
1(1,4)\end{array}$ & $\begin{array}{c}0,012 \\
(6,320)\end{array}$ \\
\hline & $\begin{array}{l}\text { Pensininkas } \\
\text { ir dirba }\end{array}$ & $\begin{array}{l}\text { Norma } \\
\text { Lengvas }\end{array}$ & $\begin{array}{l}6(75,0) \\
2(25,0)\end{array}$ & $\begin{array}{c}2(100,0) \\
0(0,0)\end{array}$ & $\begin{array}{c}2(100,0) \\
0(0,0)\end{array}$ & $\begin{array}{l}10(83,3) \\
2(16,7)\end{array}$ & $\begin{array}{c}0,549 \\
(1,200)\end{array}$ \\
\hline & Neigalusis & $\begin{array}{l}\text { Norma } \\
\text { Lengvas } \\
\text { Vidutinis } \\
\text { Sunkus }\end{array}$ & $\begin{array}{c}14(82,4) \\
1(5,9) \\
1(5,9) \\
1(5,9)\end{array}$ & $\begin{array}{c}9(75,0) \\
3(25,0) \\
0(0,0) \\
0(0,0)\end{array}$ & $\begin{array}{c}6(100,0) \\
0(0,0) \\
0(0,0) \\
0(0,0)\end{array}$ & $\begin{array}{c}29(82,9) \\
4(11,4) \\
1(2,9) \\
1(2,9)\end{array}$ & $\begin{array}{c}0,482 \\
(5,498)\end{array}$ \\
\hline
\end{tabular}

vyresnio ( $\geq 65$ metų) amžiaus ( 32,7 proc. ir 18,2 proc. ir 5,6 proc.; $p=0,003$; 6 lentelè) ir aukštesnio (mokèsi $>12$ metų) išsimokslinimo ( 31,7 proc. ir 7,1 proc. ir 5,3 proc.; $\mathrm{p}=0,009)$ bei nedirbantys $(38,9$ proc. ir 18,2 proc. ir 8,3 proc.; $\mathrm{p}=0,012)$ STEMI sergantys tiriamieji (6 lentelè).

\section{Išvados}

1. Nustatyta, kad STEMI sergantys vyrai amžiumi buvo reikšmingai jaunesni, o moterys reikšmingai vyresnès, be to, vyrai reikšmingai dažniau gyveno poroje ir dirbo, tuo tarpu moterys reikšmingai dažniau buvo vienišos ir nedirbo bei reikšmingai dažniau gavo minimalias mẻnesio pajamas, o vyrai reikšmingai dažniau (iki dviejų kartų) didesnes mènesio pajamas.

2. Nustatyta, kad gerai gydymo režimo laikèsi kas penktas, vidutiniškai - kas trečias, o blogai - kas antras STEMI sergantis tiriamasis.

3. Statistiškai reikšmingo ryšio tarp gydymo režimo laikymosi ir nerimo simptomų pasireiškimo nenustatyta, tačiau nustatyta, kad reikšmingai dažniau blogai gydymo režimo laikèsi lengvus nerimo simptomus patiriančios moterys ir nedirbantys STEMI sergantys tiriamieji.

4. Nustatyta, kad depresijos simptomų pasireiškimas statistiškai reikšmingai susijęs su gydymo režimo laikymusi: blogai gydymo režimo laikèsi patiriantys lengvus depresijos simptomus, taip pat vyresnio amžiaus, aukštesnio išsimokslinimo bei nedirbantys STEMI sergantys tiriamieji. 


\section{Literatūra}

1. World Health Organization. WHO Cardiovascular diseases (CVDs) Fact sheet [Internet]. Who. 2017. Available from: Cardiovascular diseases (CVDs).

2. Dusi V, Ghidoni A, Ravera A, De Ferrari GM, Calvillo L. Chemokines and heart disease: a network connecting cardiovascular biology to immune and autonomic nervous systems. Mediators of Inflammation, 2016.

https://doi.org/10.1155/2016/5902947

3. Khan MZ, Pervaiz MK, Iqbal M. Biostatistical analysis of modifiable risk factors of myocardial infarction. J Med Sci 2016;24(3):124-7.

4. Yanishi K, Nakamura T, Nakanishi N, Yokota I, Zen K, Yamano T. et al. A Simple risk stratification model for ST-elevation myocardial infarction (STEMI) from the combination of blood examination variables: acute myocardial infarction-Kyoto multi-center risk study group. PLoS One 2016; 11(11).

https://doi.org/10.1371/journal.pone.0166391

5. O'Gara PT, Kushner FG, Ascheim DD, Casey DE, Chung MK, De Lemos JA. et al. 2013 ACCF/AHA guideline for the management of ST-elevation myocardial infarction: a report of the American college of cardiology foundation/american heart association task force on practice guidelines. Journal of the American College of Cardiology 2013; 61.

6. Chaddha A, Robinson EA, Kline-Rogers E, Alexandris-Souphis T, Rubenfire M. Mental health and cardiovascular disease. American Journal of Medicine 2016; 129(11):1145-8. https://doi.org/10.1016/j.amjmed.2016.05.018

7. Martin LR, Williams SL, Haskard KB, DiMatteo MR. The challange of patient adherence. Ther clin risk manag [Internet]. 2005; 1(3):189-99. Available from:https://www.ncbi.nlm.nih. gov/pmc/articles/PMC1661624/pdf/tcrm0103-189.pdf

8. WHO. Adherence to longterm therapies; Evidence for action. World Health Organisation 2003.

\section{THE ASSOCIATION BETWEEN MEDICATION ADHERENCE AND ANXIETY, DEPRESSION SYMPTOMS IN PATIENTS WITH MYOCARDIAL INFARCTION}

R.Juočytė, E.Šepetauskienė, V.Adomaitienè

Key words: medication adherence, acute myocardial infarction, anxiety symptoms, depression symptoms.

Summary

The aim of the study: To determine and evaluate associations between sociodemographic factors, expression of anxiety, depression symptoms and medication adherence in patients with acute myocardial infarction with ST-segment elevation (STEMI).

Methods: A sociodemographic questionnaire, MMAS- 8 and
HADS have been used. The patients were divided into three groups according to MMAS-8. The data were analyzed using SPSS20 and Microsoft Office Excel 2010. The examined data was evaluated by calculating arithmetic mean and Standard deviation. P-values less than 0,05 were accepted to indicate statistical significance. Target group: 200 patients, that were treated in LSMUL KK Cardiology clinic during 2017-2018, for STEMI.

Results: Men were significantly younger than women, living with partner, employed $(\mathrm{p}=0,0001)$, earned more money $(\mathrm{p}=0,001)$. Bad medication adherence was determined to 47,2 pct., moderate $-31,5$ pct., good adherence $-21,3$ pct. patients. No link was revealed between medication adherence and sociodemographic factors. No anxiety disorder was found in 60,4 pct. patients, 28,4 pct was diagnosed with moderate anxiety disorder., 10,2 pct. - with mild, severe anxiety symptoms - 1 pct. No link was found between expression of anxiety symptoms and medication adherence $(\mathrm{p}=0,648)$. Statistically significant link was revealed between unemployed pensioners and women expression of mild anxiety symptoms and medication nonadherence $(\mathrm{p}=0,008)$. No depression was found in 81,2 pct. patients, 16,2 pct. was diagnosed with mild depression, 2,0 pct. with moderate, severe depression - 0,5 pct. Statistically significant link was revealed between expression of depression symptoms and medication adherence $(\mathrm{p}$ $=0,032$ ). Statistically significant link was found between patients with higher than average education $(\mathrm{p}=0,009), 65$ years old or el$\operatorname{der}(\mathrm{p}=0,003)$, unemployed pensioners $(\mathrm{p}=0,012)$ expression of mild depression symptoms and medication nonadherence.

Conclusions: 1) It was determined, that patients with STEMI significantly often were men, younger than women, living with partner, employed, earning more money, women significantly more often were elder than men, living alone, unemployed / pensioners, earning less money. 2) Good medication adherence was found in every fifth, moderate - every third and bad - every second patient with STEMI. No link between medication adherence and sociodemographic factors was investigated. 3) No link between expression of anxiety symptoms and medication adherence was found. Statistically significant link between unemployed / pensioners and women expression of mild anxiety symptoms and medication nonadherence was revealed. 4) Statistically significant link between expression of mild depression symptoms and medication nonadherence was found. Statistically significant link between patients with higher than average education, 65 years old or elder, unemployed / pensioners' expression of depression symptoms and medication non adherence was revealed.

Correspondence to: rugilejuocyte03@gmail.com

Gauta 2018-12-20 